\title{
ATYPICAL NESTING OF BONAPARTE'S GULL IN SASKATCHEWAN
}

\author{
by Robert D. Symons, Silton, Saskatchewan
}

EDITOR'S NOTE: In his "Hours and the birds," published in the fall of $1967, R$. D. Symons recalls an interesting event in the ornithological history of Saskatchewan when he relates the story of how he found a nest of the Bonaparte's Gull (Larus philadelphia) in reeds in a boggy marsh north of Jackfish Lake in the summer of 1932. This was the first nest record of this species for Saskatchewan. Mr. Symons was at that time stationed at Meota, as field officer of the Department of Natural Resources. In the following year, and again in 1935 with Fred G. Bard of the Provincial Museum of Natural History, this area was revisited by Mr. Symons, and further observations were made and evidence collected of this unusue? nesting. One of the coloured plates in Mr. Symons' book shows a pair of Bonaparte's Gulls beside such a nest in the reeds, and both this painting and the author's account of his observations of these birds nesting at Jackfish Lake have provoked considerable interest, since this species of gull has usually been observed to nest in trees.

The renewed interest taken in this breeding record made Saskatchewan naturalists aware that no previous account of Mr. Symons' observations had been published, although the Blue Jay (14:80) carried a later report by Fred G. Bard of visits made in 1955 and 1956 to the same area to field-check the Bonaparte's Gulls in "Lamotte's Swamp," as this marsh situated about 10 miles southwest of Glaslyn was known. In July, $1955 \mathrm{Mr}$. Bard saw one young Bonaparte's Gull flying with adults in a small slough about one mile south of the swamp, and in 1956 he found one nest containing three eggs. This nest was built on bulrushes of the previous year that had been somewhat flattened by the winter snow, and a sketch of it was made by Fred Lahrman to accompany Mr. Bard's article. The habitat in which the gulls nested in 1956 was also photographed by Lahrman (Figure 1), as well as the nest itself (Figure 2), and a fine painting which he did of the nesting pair of Bonaparte's Gulls at this location now hangs in $\mathrm{Mr}$. Bard's office at the Museum. On the strength of these records, Godfrey (1966) lists the location 10 miles southwest of Glaslyn in defining the breeding range of these gulls in central Saskatchewan.

Because of the renewed interest in these records we asked Mr. Symons to report his original observations in greater detail. The support of Mr. Bard and Mr. Lahrman of the Saskatchewan Museum of Natural History was enlisted, in order to substantiate the details by reference to the Museum's files and specimen collection. We are also grateful to Mr. Bard for allowing us to use his field notes of the expedition that visited the marsh in 1935 . Factual details from these notes and from the labels on the specimens in the Museum's collection have been added to Mr. Symons' narrative account.-Margaret Belcher.

It was while looking for Sandhill Cranes' nests in "Lamotte's Swamp"

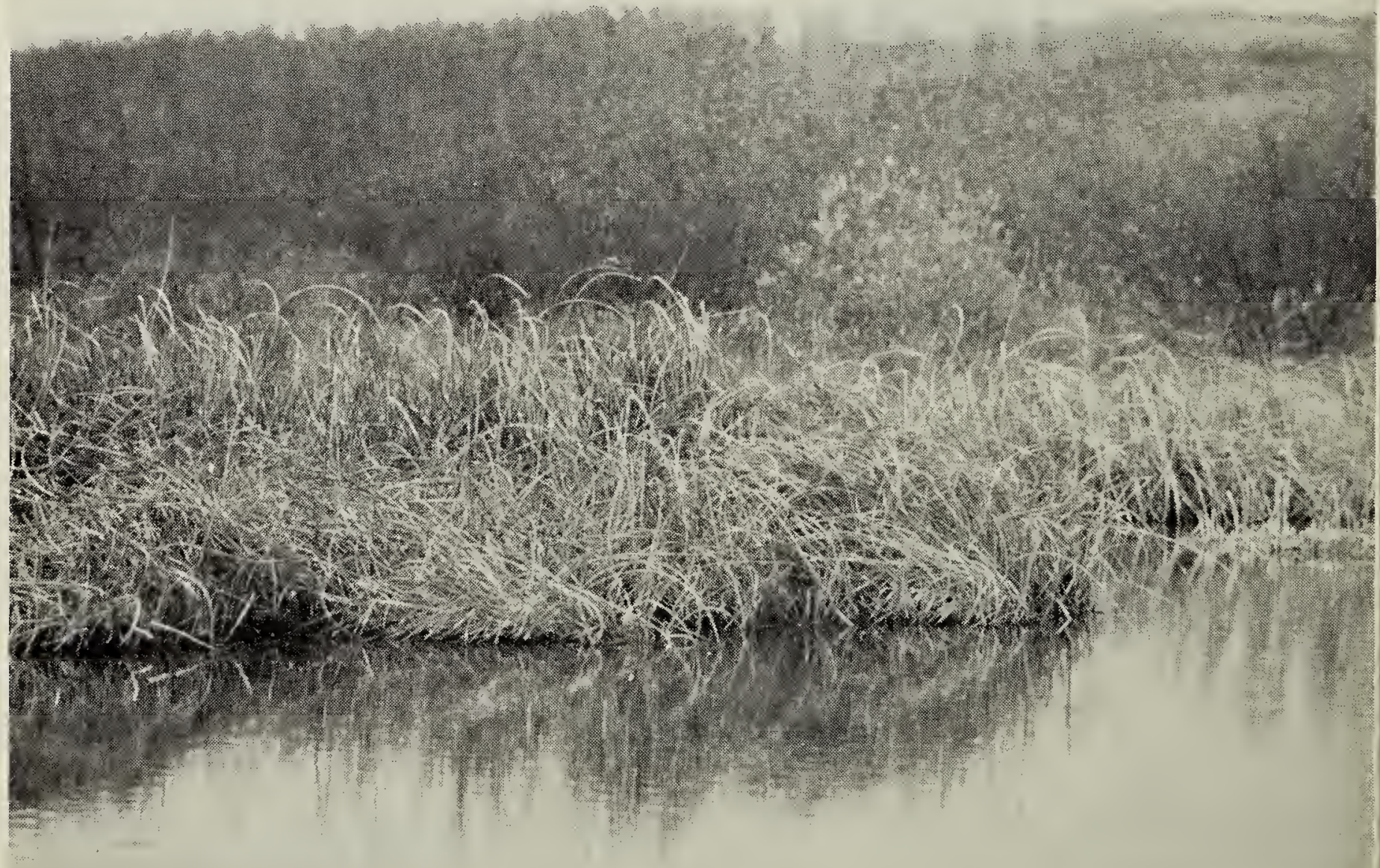

Figure 1-Lamotte's Swamp, 1956

Photo by F. W. Lahrman 
north of Jackfish Lake and south of Glaslyn in the North Battleford area, in the early summer of 1931, that I first noticed a pair of Bonaparte's Gulls and suspected they might be nesting Of course these gulls had sometimes been seen before in migration in the spring, but we did not think they nested within several hundred miles of this part of Saskatchewan. The only record we had for Saskatchewan was that given by my very good friend and adviser, Mr. H. H. Mitchell in his Catalogue of Sashatchenvan birds (1924) where he stated that they had been located "apparently breeding" at Big River" in the month of June.

It was not until May of the following year (1932) that I was able to visit the swamp again. The valley of the Jackfish Creek is from one-half to one mile wide and consists mositly of level hay land, subject to spring flooding, but in places these meadows give way to boggy areas, through which the creek winds sluggishly, its banks fringed with bulrushes and water willows, while further back, rough clumps of wire grass alternate with small stagnant pools of brown water. Several small semi-connected lakes and some flowing springs add to the general swampy nature of these muskegs. One such tract, covering about a quarter section, was the swamp in which I was interested.

Armed with sketching materials, I set out early in the morning on my search. Scanning the terrain with field glasses, I soon picked up small white dots which I felt sure were gulls. Next, donning hip waders, I proceeded in the direction of a small space of open water in the centre of the swamp, around which the flying birds seemed mostly to congregate (Figure 3). I assumed that these would be male birds, and that their brooding mates would be occupying nests at no great distance. It had looked as if it would be an easy matter to make a bee line to the lake's edge, but once in the swamp itself one seemed almost completely losit, knee-deep in the brackish water and surrounded by the high tussocks of wire grass, mixed with small silver swamp willow and the pretty little Labrador tea. Occasionally, mounting a quaking hummock, I could catch a silvery gleam from the water ahead, which served to guide me, and so I entered the beds of bulrushes, full of treacherous holes, where the footing had to be carefully felt out before a step was taken. The sun beat down fiercely and the mosquitoes bit wickedly, but the anticipation of an interesting discovery encouraged me to press on.

As I approached the lake, two gulls circled me at some distance. I carefully considered the possibility that these gulls might prove to be the somewhat similarly marked, and much more common, Franklin's Gulls, or secondly, that they might be nonbreeding Bonaparte's Gulls. However, their appearance in flight pointed to their being philadelphia.

Soon I was among the clumps and rafts of last year's dead bulrushes, through which the present season's growth was pushing upward. These clumps were quite firmly matted and compressed by the weight of the deep snow of the preceding winter and in places they were even firm enough to bear one's weight sitting down. I decided that the birds might be nesting in or on these clumps. Just as I was beginning a systematic search, a gull charged me with a harsh screaming note. She swooped so fast and straight that for a moment I was fearful of being impaled by the sharp bill, but when she was a few feet from my head she put on the brakes and turned straight up, only to check herself in mid-air and swoop back from the reverse direction. I say "she", for I was certain from her actions that this bird was a female, and indeed, the few wheeling, circling birds I had first observed had not changed their direction.

Constantly she uttered her screaming note, much more tern-like than gull-like. I have never heard this species "mew" in the manner of the Franklin's Gull. In the instant that she swerved to pass over my head, I 


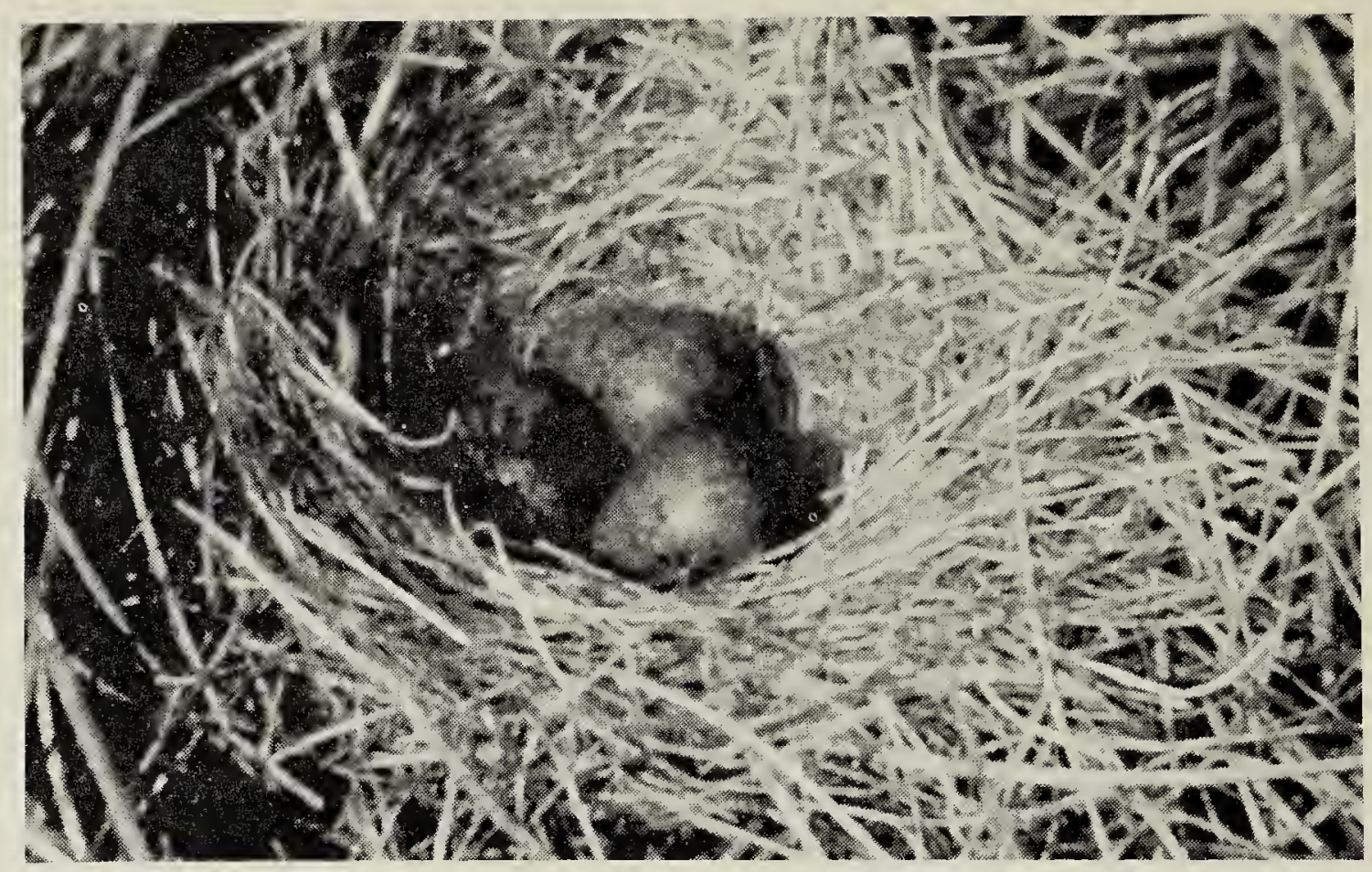

Photo by F. W. Lahrman

Figure 2-Nest of Bonaparte's Gull in Lamotte's Swamp, 1956

noticed the dark bill, the bright coral legs, and the large amount of white about the "wrist" of the wing, and these points, together with the ternlike note and flight, and the much more slender and delicate build, settled any doubts that I might have held as to the identity of the species.

For over an hour I searched the clumps of bulrushes, but to no avail. By now two other birds, apparently females, had joined the attacker, launching themselves, like her, from out of the blue, and from now on these three s'wept continuously over our heads, while to add to the general clamour a number of Black Terns suddenly appeared from nowhere and joined them in abusing us, and Marbled Godwits attracted by the disturbance shrieked their defiance, like selfappointed guardians of the marsh.

Finally I gave up the search, after examining hundreds of clumps of bulrushes without result, and reiturned to the shore of the marsh for lunch before taking up the search again. When I returned, I went to a point a little west of where I had first come upon the open water, keeping my eyes glued on the reed clumps, but again I was taken by surprise and charged by a female gull. This time, however, I stood quietly in the partial conceal- ment of a clump of willows, and after a few minutes my patience was rewarded by seeing the bird, after a couple of circling flights, suddenly alight with indescribable grace on the summit of a reed clump about 100 yards away. As I watched, a male bird joined her. As soon as he lit, the female again launched herself in the air, leaving him standing statuesquely with folded wings. His mate again circled us, but as I did not move she flew straight to her partner and almost immediately settled down, shuffling her wings and puffing out her breast in the unmisitakable movements of a brooding bird.

Exultantly I marked the spot, and slowly approached. The male took flight as soon as I moved, but I was quite close before his mate, who by this time had settled down until only her bill and tail showed over the nest rim, suddenly launched herself at me in the manner which I now expected. In a few moments I stood beside the nest with its three olive eggs with their dark markings.

The nest was a neat affair, unlike the untidy and often damp mass reared by the Franklin's Gull, being a sort of natural hollow in the clump of dead bulrushes, neatly shaped and rounded and provided with a lining 
of fine sedges and grasses with a few small willow twigs interwoven. By actual measurement it was three feet and two inches above the surface of the surrounding water, and therefore perfectly high and dry.

Hastily I took out my sketch book and pencil to make a number of quick studies, and I was more than usually careful with my sketches and my notes because I realized that this would be the first recorded nest of this species for Saskatchewan. For this reason also, I had borrowed a small box camera in order to take photographs, and I was able to photograph the nest (Figure 4). Before leaving the swamp I was fortunate enough to find another nest containing eggs only a short distance from

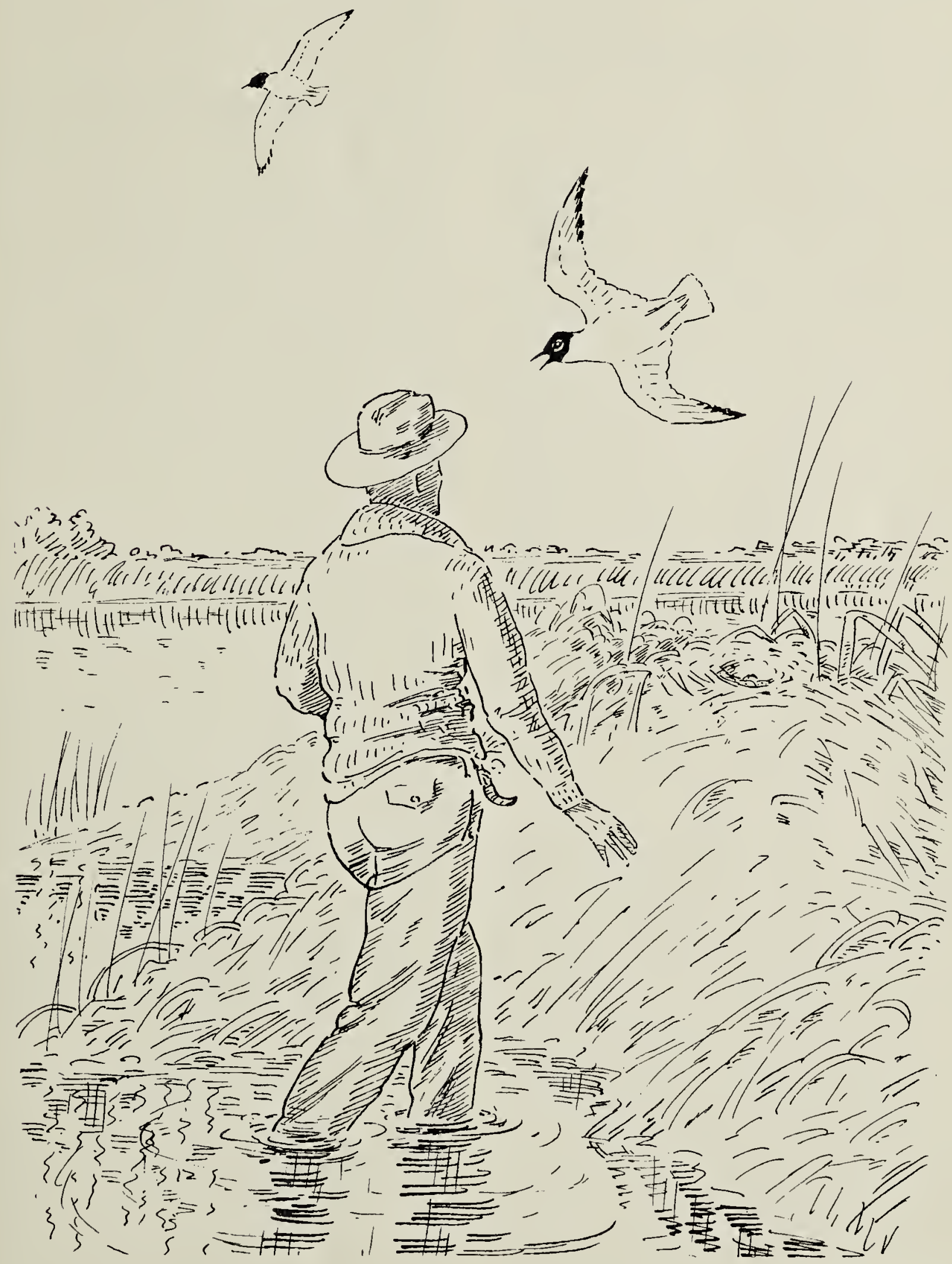

Sketch by R. D. Symons, 1932

Figure 3-Discovering the nests of the Bonaparte's Gull in Lamotte's Swamp 


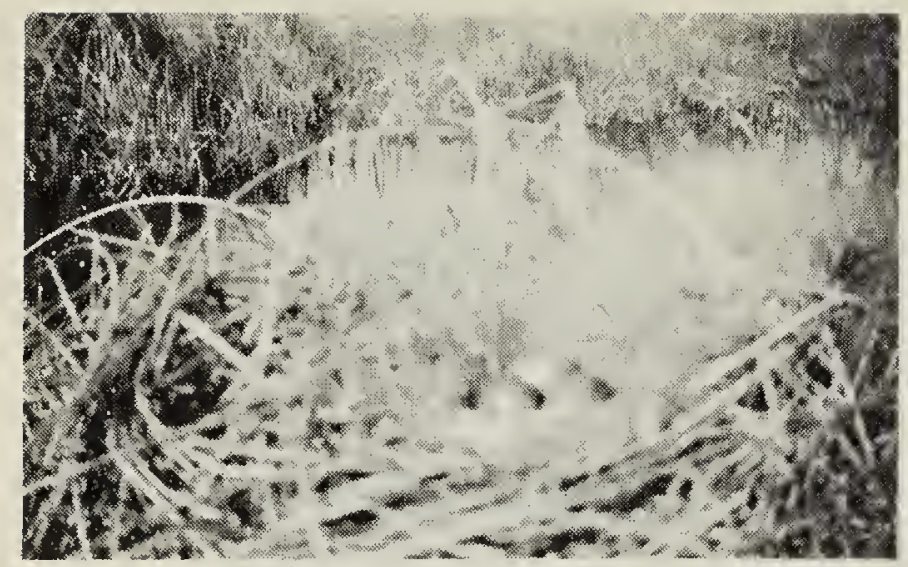

Photo R.D.S.

Figure 4-Nest of Bonaparte's Gull in Lamotte's Swamp, May 27, 1932

the first, and from my observations I reckoned that there would be no less than six breeding pairs in the swamp.

It was, as I suspected, diricult to persuade others of the authenticity of the record. Accordingly, in the following year (1933) I revisited the nesting site with Conrad Reid of Meota whom I had engaged to help me collect a specimen. I sent this specimen and egg's from the nest to Mr. Fred Bradshaw at the Provincial Museum. [This specimen, collected May 31, 1933 north of Meota by R. D. Symons is preserved as a study skin (Specimen No. 3195) at the Saskatchewan Museum of Natural History. The label indicates that it was a female bird, shot near its nest $18^{\prime \prime}$ above muskeg, and also that the nest and three eggs were taken.-M.B.]

Two years later (1935) representatives from the Provincial Museum accompanied me to this spot for further observations, and specimens were again collected. A pair of these birds and their nest with its three eggs were used for a habitat group at the $\mathrm{Mu}$ seum, for which I was commissioned to paint the background. In this habitat group the reeds on which the nest is placed are the original bulrushes taken from the site with the nest.

In 1935 representation was made by the Museum to the Department of Natural Resources to have the quarter section which comprised the major part of this swamp set aside as a bird sanctuary for the chief reason of offering protection to the small colony of Bonaparte's Gulls which nested there. This request was complied with, and the area suggested gazetted under the name of "Marais des Oiseaux" because this is a French-Canadian settlement. I understand, however, that the sanctuary is no longer in existence, and the breeding site itself needs further investigation to see whether Bonaparte's Gulls are still nesting there in the summer.

FINAL NOTE: The notes kept by Mr. Bard of the field trip made by a Museum party in early 1935 to the Battleford area give further details of the findings of that visit. Dunk (1936) cites these notes: "On May 19th, five Bonaparte's Gulls were seen resting on broken down tule reeds. On June 3rd, Mr. Symons found the first nest, which contained three eggs. Shortly after a second nest was found by Mr. Bard. This also contained three eggs. A second visit to this nest on June 20th showed two young birds and a chipped egg. Three hours later it was observed that the third young bird had just emerged from its shcll. These nests were found in isolated clumps of tule reeds and were built on the old matted reeds, the lower part of the nests being constructed of these reeds topped by dead grasses. The nests were compact and well made in the form of a basin and measured six inches across.

"It is of interest to note that the nests of these gulls have usually been found in trees. Although this colony is small, they have evidently nested here for some time in the manner described, as many old nests were found. Photographs were taken and all necessary material collected for a habitat group."

This habitat group, which can be seen at the Saskatchewan Museum of Natural History, is entitled "Lamotte's Swamp Group - Glaslyn." A single Sandhill Crane standing in the marsh is featured in the accompanying panel which describes the group, and the Bonaparte's Gulls only get mention in the list of other species frequenting the marsh. Perhaps for this reason, the unusual nesting site of the Bonaparte's Gulls in the reeds has often escaped notice.

In addition to the pair of birds which appear in the habitat case with nest and eggs, the SMNH collection includes study skins \#3195 (Symons' 1933 specimen), \#3585 (male), \#3586 (female), \#3632 (chick), nests \#3587, \#3633, \#3634, and eggs \#3588.-M.B.

\section{LITERATURE CITED}

Dunk, F. A. 1936. Report of the Director, Pruvincial Museum, Dept. of Nat. Resources, for year ending April 30, 1936. In Govt. of Sask., Dept. of Nat. Resources, Annual Report for the year ending April 30, 1936.

Godfrey, W. E. 1966. The birds of Canada. Natl. Mus. Can. Bull. No. 203, Biol. Series No. 73. Ottawa.

Mitchell, H. H. 1924. Birds of Saskatchewan. Can. Field-Nat., 38 (6): 101-118. 